\title{
PENGARUH MEDIA KARTU KUARTET TERHADAP PRESTASI BELAJAR SISWA DALAM TEMA 7 SUBTEMA 2 DI INDONESIA
}

\section{THE EFFECT OF THE QUARTET CARD MEDIA ON STUDENT ACHIEVEMENT IN THEME 7 SUB-THEME 2 IN INDONESIA}

\author{
Nisa Awaliyah $^{1 *}$, M. Fahmi Nugraha ${ }^{2}$, Budi Hendrawan ${ }^{3}$ \\ 1,2,3 FKIP Universitas Muammadiyah Tasikmalaya, Indonesia \\ 1awaliyahnisa773@gmail.com \\ 2m.fahminugraha@umtas.ac.id \\ 3hendrawan_budy@umtas.ac.id
}

DOI: $10.35438 /$ cendekiawan.v3i2.205

Article Info

Historical Articles

Submitted: 2021-01-29

Revised: 2021-11-10

Issued: 2021-12-30

Keywords: Quartet card learning method, learning achievement

Kata kunci: Metode pembelajaran kartu kuartet, prestasi belajar
Based on the problem in the learning process, the application of the quartet card learning media is expected to improve student achievement in class IV material at SDN 1 Linggawangi. This type of research is quantitative research with experimental methods; the design used is quasi-experimental with one-group pretest-posttest. The study was conducted at SDN 1 Linggawangi with 20 students using a saturated sample by dividing students into two classes, namely the control class with ten students and the experimental class with ten students. Data collection techniques are by conducting observations, unstructured interviews, documentation, values. The validity of the instrument the researcher conducted expert judgment. The results obtained In the experimental class students when the learning process took place students became focused and enthusiastic in participating in the learning process and had an effect on student achievement with the results obtained from the posttest average value with a more significant increase than the control class, namely 83.5> 61,5.

\section{Abstrak}

Berdasarkan masalah pada proses pembelajaran tersebut maka melalui penerapan media pembelajaran kartu kuartet diharapkan mampu meningkatkan prestasi belajar siswa pada materi gaya kelas IV SDN 1 Linggawangi. Jenis penelitian ini adalah penelitian kuantitatif dengan metode eksperimen, desain yang digunakan quasi experimental dengan one-group pretest-posttest. Penelitian dilakukan di SDN 1 Linggawangi dengan populasi 20 orang siswa denga menggunakan sampel jenuh dengan membagi siswa kedalam dua kelas yaitu kelas kontrol sepuluh siswa dan kelas eksperimen sepuluh siswa. teknik pengumpulan data yaitu dengan melakukan observasi, wawancara tidak tersetruktur, dokumentasi, nilai. validitas instrumen peneliti melakukan expert judgement. Hasil yang didapat Pada siswa kelas eksperimen saat proses pembelajaran berlangsung siswa menjadi fokus dan antusias dalam mengikuti proses pembelajaran dan berpengaruh pada prestasi belajar siswa dengan hasil yang diperoleh dari nilai ratarata posttest dengan adanya peningkatan lebih besar dari kelas kontrol yaitu 83,5 > 61,5.

\section{PENDAHULUAN}

Pendidikan adalah salah satu aspek penting bagi kehidupan manusia. Pendidikan yang berkualitas sangat diperlukan untuk mendukung terciptanya manusia yang cerdas serta mampu bersaing di era globalisasi. Dalam Undang-Undang nomor 20 tahun 2003 tentang Sistem Pendidikan Nasional Bab 1 pasal 1 menyebutkan bahwa pendidikan adalah usaha sadar dan terencana untuk mewujudkan 
suasana belajar dan proses pembelajaran agar peserta didik secara aktif mengembangkan potensi dirinya untuk memiliki kekuatan spiritual keagamaannya, akhlak mulia serta keterampilan yang diperlukan dirinya, masyarakat, bangsa dan negara. (Jalil, 2016) IPA adalah suatu kumpulan teori yang sistematis, penerapannya secara umum terbatas pada gejala-gejala alam, lahir, dan berkembang melalui metode ilmiah seperti observasi dan eksperimen serta menuntut sikap ilmiah seperti rasa ingin tahu, terbuka, jujur, dan sebagainya. Dalam proses pembelajaran IPA di SDN 1 Linggawangi memiliki kesulitan dalam proses pembelajaran sehingga nilai yang didapat masih dibawah KKM. Siswa yang mencapai KKM hanya $33 \%$ sedangkan yang belum mencapai KKM mencapai $66 \%$. Penyebab yang mempengaruhi nilai pembelajaran IPA rendah yaitu guru menjadi pusat dalam proses pembelajaran, kurangnya media pembelajaran yang digunakan oleh guru dalam proses pembelajaran, sehingga siswa merasa bosan dan kurang aktif di kelas. Prastowo (2014: 1-13) karakteristik perkembangan peserta didik SD/MI dapat dipilah menjadi dua macam yaitu perkembangan pada aspek jasmaniah dan perkembangan pada aspek mental. Pada aspek jasmaniah, peserta didik SD/MI telah memiliki kematangan sehingga mampu mengontrol tubuh dan keseimbangannya. Sedangkan pada aspek mental yang meliputi perkembangan intelektual, bahasa, sosial, emosi dan moral keagamaan. Jean Piaget, karakteristik siswa kelas IV termasuk ke dalam tahap operasional konkret. Ciri pokok perkembangan pada tahap ini adalah anak sudah mulai menggunakan aturan-aturan yang jelas dan logis, ditandai adanya reversible dan kekekalan. Anak sudah tidak perlu coba-coba dan membuat kesalahan, karena anak sudah dapat berpikir dengan menggunakan model "kemungkinan" dalam melakukan hasil yang telah dicapai sebelumnya. Untuk mengatasi permasalahan dalam proses pembelajaran tersebut agar prestasi belajar siswa tidak rendah maka perlu diterapkan media pembelajaran yang dapat membangkitkan dan melibatkan keaktifan siswa dalam proses pembelajaran yaitu dengan menerapkan media pembelajaran kartu kuartet.

Kartu kuartet merupakan permainan pada jaman dahulu yang sangat digemari oleh anak-anak, karena permainan ini menampilkan pendeskripsian kata serta gambar yang menarik. Arsyad (2006: 119-120) mengemukakan bahwa kartu kuartet adalah kartu kecil yang berisi gambar, teks, atau tanda simbol yang mengingatkan dan menuntun anak kepada sesuatu yang berhubungan dengan materi yang sedang dipelajari. (Giwangsa, 2021) menyatakan bahwa kartu kuartet adalah sejenis permainan yang terdiri atas beberapa jumlah kartu bergambar yang dari kartu tersebut tertera keterangan berupa tulisan yang menerangkan gambar tersebut. Biasanya tulisan judul gambar ditulis paling atas dari kartu dan tulisannya lebih diperbesar atau dipertebal. Sedangkan tulisan gambar, ditulis dua atau empat baris secara vertikal di tengah-tengah antara judul dan gambar. Tulisan yang menerangkan gambar itu biasanya ditulis dengan tinta berwarna (Trisnawati, 2013). Ukuran dari kartu kuartet ini biasanya beragam, ada yang ukurannya kecil dan sedang (Sari et al., 2017). Jumlah kartu dalam kartu kuartet ada 48 lembar kartu, berarti memiliki 12 judul yang masing-masing memiliki 4 buah kartu. Dapat diartikan bahwa kartu kuartet merupakan permainan pada jaman dahulu yang sangat digemari oleh anak-anak, karena permainan ini menampilkan pendeskripsian kata serta gambar yang menarik. Kartu kuartet berukuran $8 \times 12 \mathrm{~cm}$ terdiri dari sejumlah set kartu bergambar dengan tema yang telah ditentukan. Pada setiap kartu terdapat judul dan sub judul untuk menjelaskan gambar tersebut (Sasmita, 2017). Pada setiap kartu terdapat judul di bagian tengah atas, sedangkan di atas gambar terdapat kata-kata yang merupakan sub tema.

Dalam penggunaan media pembelajaran kartu kuartet ini, terdapat langkah-langkah yaitu menjelaskan tentang apa permainan kuartet itu dan bagaimana cara bermainnya (Karsono et al., 
2014), salah satu pemain mengocok kartu dan membagikan pada masing-masing pemain empat buah, sisa kartu diletakkan ditengah meja dengan posisi tertutup, permainan dilakukan searah dengan jarum jam, setelah di undi untuk memperoleh pemain pertama, untuk memulai permainan, pemain tersebut bertanya pada pemain lain apakah dia mempunyai kartu dengan kategori tertentu, jika jawaban "tidak" pemain tersebut hilang gilirannya, kemudian mengambil sebuah kartu di atas meja dan permainan dilanjutkan ke pemain berikutnya, jika jawaban "ya" pemain bertanya lagi dengan bertujuan untuk mendapatkan kartu dengan entry yang digarisbawahi yang tidak sama dengan yang dia miliki, jika jawaban "ya" pemain tersebut menerima kartu yang dicari, dia kemudian melanjutkan bertanya pada pemain lain untuk kategori lain atau entry yang digarisbawahi lainnya sampai dia mendapatkan jawaban negatif, permainan kemudian diberikan pada pemain berikutnya, setelah masing-masing mendapat giliran, para pemain yang kartunya kurang dari empat buah harus melengkapinya dengan mengambil kartu dari tumpukan kartu di atas meja, kuartet yang lengkap disisihkan atau disimpan untuk dihitung pada akhir permainan, permainan berakhir ketika sepuluh kuartet tersebut semuanya telah dikumpulkan oleh para pemain, kemudian dihitung berapa perolehan kartu yang lengkap dan yang perolehannya terbanyak yang menjadi pemenang.

Proses pembelajaran dilakukan oleh guru dan siswa untuk memberikan pengetahuan kepada siswa. Setelah proses pembelajaran dilakukan guru melakukan pengukuran kemampuan siswa yang berkenaan dengan penguasaan bahan pelajaran yang disajikan pada nilai-nilai. Muhammad Fathurrahman dan Sulistyorini (2012) prestasi adalah suatu hasil luar biasa/dahsyat yang telah dicapai dan prestasi merupakan sebuah keberhasilan berstandar tinggi yang citranya hanya diperoleh segelintir orang. (Istiningsih, 2017) belajar adalah suatu aktivitas mental/psikis, yang berlangsung dalam interaksi aktif dengan lingkungan, yang menghasilkan sejumlah perubahan dalam pengetahuan-pemahaman, keterampilan dan sikap-sikap.

Arifin (2011: 12) menyatakan bahwa prestasi belajar pada umumnya berkaitan dengan aspek pengetahuan yang dapat diketahui melalui evaluasi dan diwujudkan dalam bentuk angka atau nilai. Suryabrata (2011: 5), prestasi belajar sebagai nilai yang merupakan bentuk perumusan akhir yang diberikan oleh guru terkait dengan kemajuan atau prestasi belajar siswa selama waktu tertentu. Rozalia (2017: 726) prestasi belajar merupakan kemampuan siswa dalam memahami materi, mengerjakan tugas saat belajar disekolah yang diberikan guru. prestasi belajar adalah hasil yang diperoleh berupa suatu perubahan sebagai hasil dari aktivitas belajar sehingga dapat mencapai tujuan. Prestasi belajar siswa dapat dilihat dari dari hasil penilaian atau evaluasi yang dinyatakan dengan angka, huruf atau kalimat sehingga guru dapat dengan mudah menentukan tinggi rendahnya prestasi belajar siswa.

Ilmu Pengetahuan Alam merupakan ilmu yang mempelajari mengenai gejala alam yang dihasilkan berdasarkan observasi. (Akmal \& Susanti, 2019) Ilmu Pengetahuan Alam merupakan terjemahan kata-kata Inggris, yaitu natural sciences artinya ilmu pengetahuan alam. Jadi IPA atau science itu dapat disebut sebagai ilmu tentang alam atau ilmu yang mempelajari tentang peristiwa-peristiwa yang terjadi di alam ini. IPA membahas tentang gejala-gejala alam yang disusun secara sistematis yang didasarkan pada hasil percobaan dan pengamatan yang dilakukan oleh manusia. Trianto dalam (Reni et al., 2020) IPA adalah suatu kumpulan teori yang sistematis, penerapannya secara umum terbatas pada gejala-gejala alam, lahir dan berkembang melalui metode ilmiah seperti observasi dan eksperimen serta menuntut sikap ilmiah seperti rasa ingin tahu, terbuka, jujur, dan sebagainya. Dapat 
Nisa Awaliyah, M. Fahmi Nugraha, Budi Hendrawan/Cendekiawan Vol 3 (No. 2) (2021)

disimpulkan bahwa hakikat IPA adalah ilmu tentang gejala alam berupa fakta yang yang dihasilkan berdasarkan observasi di lapangan meliputi ilmu pengetahuan. Pembelajaran IPA di Sekolah Dasar mengembangkan aktivitas belajar siswa untuk mencari tahu tentang materi IPA dan pemahaman pada materi pembelajaran IPA yang diajarkan oleh pendidik.

\section{METODE}

Penelitian yang digunakan adalah kuantitatif. Metode penelitian yang digunakan dalam penelitian ini adalah metode eksperimen, jenis penelitian yang digunakan yaitu quasi experimental dan desain yang digunakan adalah one group design.

Populasi dalam penelitian ini yaitu seluruh siswa kelas IV SDN 1 Linggawangi yang berjumlah 20 siswa. Sample yang digunakan adalah sampling jenuh, menurut Sugiyono (2016: 124) sampling jenuh adalah teknik penentuan sampel bila semua anggota populasi digunakan sebagai sampel. Hal ini sering dilakukan bila jumlah populasi relatif kecil, kurang dari 30 orang atau penelitian yang ingin membuat generalisasi dengan kesalahan yang sangat kecil. Dalam menentukan kelompok kontrol dan eksperimen dengan cara di random yaitu 10 siswa kelompok kontrol dan 10 siswa kelompok eksperimen. Jumlah sampel yang digunakan yaitu kelas IV sebanyak 20 siswa. Penelitian ini dilaksanakan di SDN 1 Linggawangi dan pelaksanaan penelitian dilakukan pada bulan Juli 2020.

Pada penelitian ini menggunakan variabel bebas yaitu media pembelajaran kartu kuartet dan variabel terikatnya yaitu prestasi belajar siswa pada materi gaya. Instrumen penelitian menggunakan instrumen tes. Sedangkan teknik pengumpulan data yaitu dengan melakukan observasi, wawancara tidak tersetruktur, dokumentasi, nilai. Validitas dilakukan untuk mengukur suatu instrumen yang telah dibuat sebelumnya. Sukmadinata (2016: 228) validitas instrumen menunjukan bahwa hasil dari suatu pengukuran menggambarkan segi atau aspek yang diukur.

Dalam melakukan validitas instrumen peneliti melakukan expert judgement yaitu kepada dosen ahli bidang IPA dan kepada dosen ahli bidang bahasa. Kemudian melakukan uji coba instrumen soal dengan menggunakan korelasi pearson product moment dengan SPSS versi 20 dengan ketentuan $r_{\text {hitung }}>$ $r_{\text {tabel }}$ maka instrumen valid namun sebaliknya jika $r_{\text {hitung }}<r_{\text {tabel }}$ maka instrumen tidak valid. Reliabilitas merupakan tes yang dapat dipercayai sesuai kriteria yang telah ditetapkan.

Teknik analisis data yang digunakan yaitu menggunakan statistik. Peneliti melakukan uji normalitas menggunakan Shapiro-Wilk pada SPSS versi 20 (Ai Parihah, M. Fahmi Nugraha, 2020). Jika nilai signifikansi pada Shapiro-Wilk $<0,05$ maka data berdistribusi tidak normal dan jika nilai signifikansi pada Shapiro-Wilk $>0,05$ maka data berdistribusi normal. Uji homogenitas digunakan untuk mengetahui apakah data sebelum dan sesudah perlakuan memiliki varians yang sama atau tidak. Untuk mengukur homogenitas varians yang di input dari kelas eksperimen dan kelas kontrol, dalam penelitian ini menggunakan Anova satu arah (Anova one way) menggunakan SPSS versi 20 menggunakan taraf signifikansi sebesar 5\% dengan kriteria jika signifikan $>0.05$ maka $\mathrm{H}_{\mathrm{o}}$ diterima dan jika signifikan $<0.05$ maka $\mathrm{H}_{\mathrm{o}}$ ditolak. Uji hipotesis dilakukan untuk membuktikan hipotesis yang dibuat diterima atau ditolak. Setelah melakukan uji normalitas dan uji homogenitas maka dilakukan uji hipotesis apabila sudah berdistribusi normal maka data digunakan dengan menggunakan uji dua pihak (two tail test) dengan menggunakan SPSS versi 20. Menurut Sugiyono (2019: 262) uji dua pihak digunakan bila hipotesis nol $\left(\mathrm{H}_{\mathrm{o}}\right)$ berbunyi "sama dengan" dan hipotesis alternatif $\left(\mathrm{H}_{\mathrm{a}}\right)$ berbunyi “tidak sama dengan" $\left(\mathrm{H}_{\mathrm{o}}=; \mathrm{H}_{\mathrm{a}} \neq\right)$.

Dengan hipotesis statistik sebagai berikut:

$\mathrm{H}_{\mathrm{o}} \quad$ : Tidak terdapat pengaruh media pembelajaran kartu kuartet terhadap prestasi belajar siswa kelas IV SDN 1 Linggawangi materi gaya. 
$\mathrm{H}_{\mathrm{a}} \quad$ : Terdapat pengaruh media pembelajaran kartu kuartet terhadap prestasi belajar siswa kelas IV SDN 1 Linggawangi materi gaya.

Dengan hipotesis statistik sebagai berikut:

$\mathrm{H}_{\mathrm{o}}: \mu 1=\mu 2$

$\mathrm{H}_{\mathrm{a}}: \mu 1 \neq \mu 1$

\section{HASIL PENELITIAN}

Penelitian dilakukan di SDN 1 Linggawangi Kecamatan Leuwisari Kabupaten Tasikmalaya. Penelitian ini telah dilakukan pada seluruh siswa kelas IV SDN 1 Linggawangi berjumlah 20 siswa, yang dibagi menjadi dua kelas diantaranya 10 siswa kelas eksperimen yang diberikan perlakuan dengan media pembelajaran kartu kuartet dan 10 siswa kelas kontrol diberikan perlakuan dengan menggunakan model pembelajaran konvensional dalam bentuk ceramah. Penelitian dilakukan untuk mengetahui pengaruh media pembelajaran kartu kuartet terhadap prestasi belajar siswa pada mata pelajaran IPA materi gaya pada siswa kelas IV.

Pertama yang dilakukan yaitu pretest dilakukan oleh seluruh siswa kelas IV dan hasil yang didapat dari pretest kelas kontrol memiliki nilai rata-rata 54,5 dan kelas eksperimen memiliki nilai ratarata 60,0 sehingga nilai rata-rata kelas eksperimen dan kelas kontrol memiliki nilai rata-rata yang tidak jauh berbeda. Selanjutnya peneliti memberikan perlakuan kepada kelas eksperimen dengan perlakuan menggunakan media pembelajaran kartu kuartet sedangkan kelas kontrol diberi perlakuan dengan menggunakan model pembelajaran konensional. Setelah selesai diberi perlakuan kedua kelas diberikan posttest untuk mengetahui hasil perlakuan yang telah diberikan dan nilai rata-rata kelas eksperimen yaitu 83,5 sedangkan kelas kontrol nilai rata-ratanya yaitu 61,5. Nilai rata-rata kelas ekperimen lebih tinggi dibandingkan dengan kelas kontrol sehingga jauh berbeda. Berdasarkan validitas menggunakan SPSS versi 20 dinyatakan semua valid dari seluruh soal yang berjumlah 20 soal. Dari pernyataan tersebut dapat dibuat grafik nilai pretest kelas kontrol dan kelas eksperimen sebagai berikut:

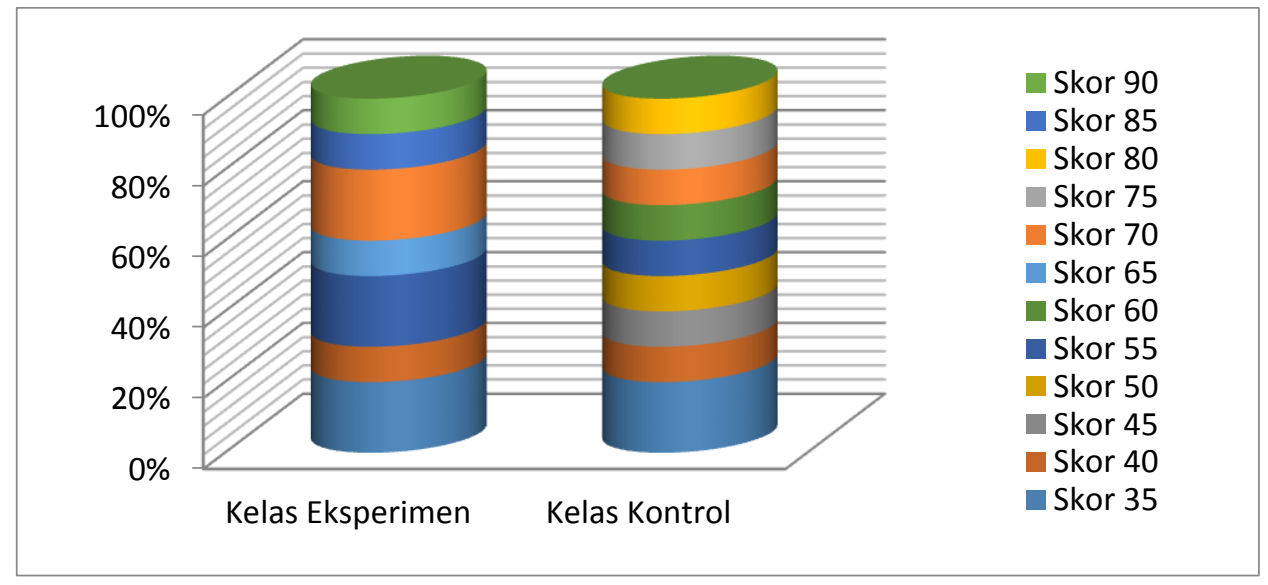

Gambar 1. Gambar grafik nilai hasil pretest

Berikut gambar 2 grafik nilai hasil posttest kelas eksperimen dan kelas kontrol sebagai berikut: 
Nisa Awaliyah, M. Fahmi Nugraha, Budi Hendrawan/Cendekiawan Vol 3 (No. 2) (2021)

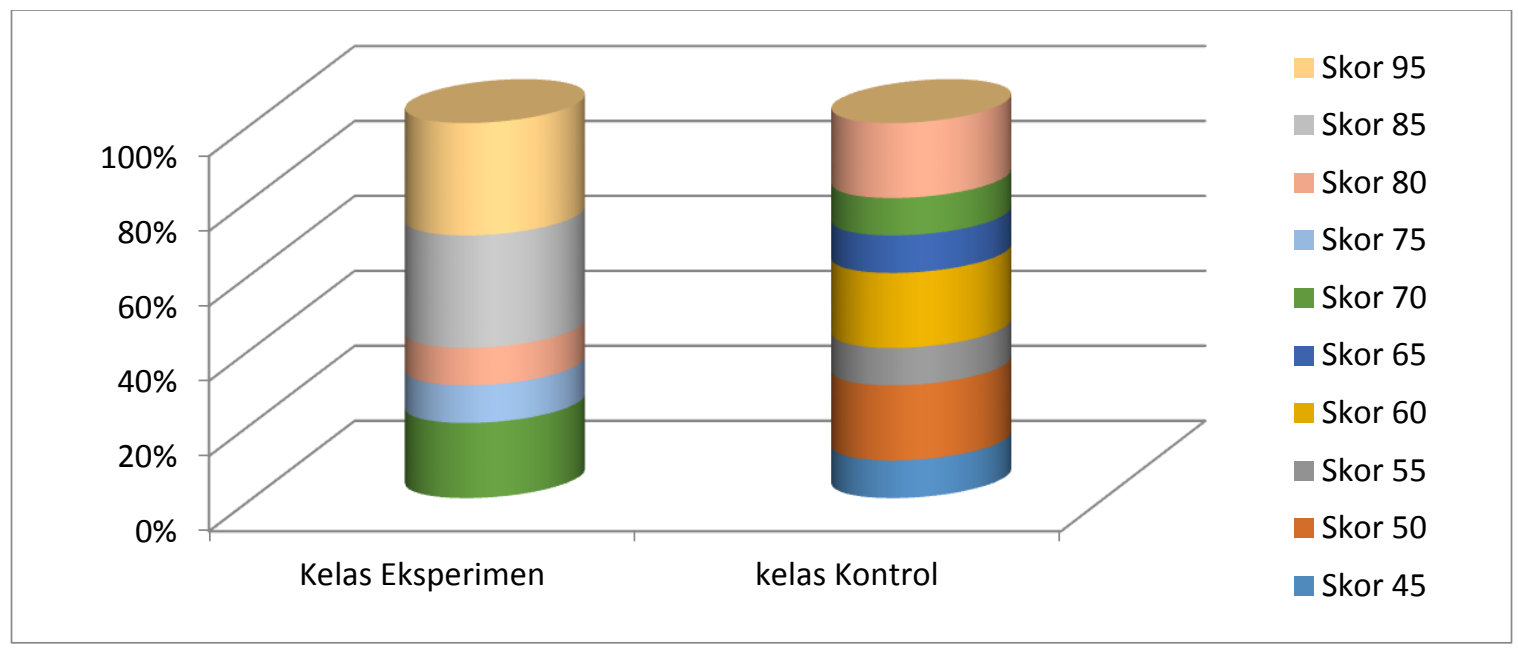

Gambar 2. Gambar grafik nilai hasil posttest

Pengujian reliabilitas dilakukan untuk mengetahui tingkat kekonsistetan soal menggunakan SPSS dengan hasil sebagai berikut:

Tabel 1. Hasil uji reliabilitas

\begin{tabular}{ccc}
\hline Bentuk Instrumen & Cronbach's Alpha & Keputusan \\
\hline Pilihan Ganda & 0.907 & Reliabel \\
\hline
\end{tabular}

Dari hasil uji reliabilitas diatas, dapat disimpulkan bahwa reliabilitas instrument pada penelitian ini dapat dikatakan dalam kriteria ini reliabel karena koefisien reliabilitas instrumen ini $0.907>0.444$ maka hasilnya reliable.

\section{Uji Normalitas Data}

Uji normalitas menggunakan uji Shapiro-Wilk dengan SPSS versi 20. Dengan ketentuan jika sig $<0.05$ maka data tidak berdistribusi normal dan jika nilai sig $>0.05$ maka data berdistribusi normal. Hasil pengolahan data uji normalitas dapat dilihat pada tabel berikut ini:

Tabel 2. Uji normalitas data shapiro-wilk

\begin{tabular}{ccccc}
\hline \multirow{2}{*}{ KELAS } & \multicolumn{3}{c}{ Shapiro-Wilk } & \multirow{2}{*}{ Kesimpulan } \\
\cline { 2 - 4 } & Statistic & Df & Sig. & \\
\hline Pretest Eksperimen & .931 & 10 & .458 & Normal \\
\hline Post Test Eksperimen & .885 & 10 & .149 & Normal \\
\hline Pretest Kontrol & .929 & 10 & .442 & Normal \\
\hline Post Test Kontrol & .930 & 10 & .447 & Normal \\
\hline
\end{tabular}

Berdasarkan tabel diatas, dapat disimpulkan bahwa jika dilihat dari nilai sig pada kolom Shapiro-wilk pretest eksperimen yaitu 0,458 , nilai posttest eksperimen 0,149 , nilai pretest kontrol 0,442 dan nilai posttest kontrol 0,447. Dalam hal ini, signifikansi semua data hasil belajar siswa tersebut lebih besar dari taraf signifikansi $0,05(0,458>0,05),(0,149>0,05),(0,442>0,05)$, dan $(0,447>0,05)$. Sehingga dapat disimpulkan bahwa data berdistribusi normal karena semua nilai signifikansi lebih dari 0,05 . 


\section{Uji Homogenitas}

Uji homogenitas untuk mengetahui kedua data tersebut bersifat homogen sama atau tidak. Dalam penelitian ini uji homogenitas menggunakan rumus One Way Anova dengan perhitungan SPSS versi 20 berikut ini:

Tabel 3. Hasil uji homogenitas pretest

\begin{tabular}{rrrrr}
\hline Levene Statistic & $d f 1$ & $d f 2$ & Sig. \\
\hline & .378 & 1 & 18 & .547 \\
\hline
\end{tabular}

Tabel 4. Hasil uji homogenitas posttest

\begin{tabular}{cccr}
\hline Levene Statistic & $d f 1$ & $d f 2$ & \multicolumn{2}{c}{ Sig. } \\
\hline .566 & 1 & 18 & .462 \\
\hline
\end{tabular}

Berdasarkan hasil uji homogenitas dari hasil pretest dan posttest kelas eksperimen dan kelas kontrol dapat diketahui bahwa hasil dari pretest nilai signifikansi yang diperoleh sebesar 0,547 > 0,05 dan hasil dari posttest nilai signifikansi yang diperoleh sebesar 0,462 >0,05. Maka dapat disimpulkan bahwa nilai signifikansi pretest dan posttest kelas eksperimen dan kelas kontrol bersifat homogen karena nilai sig $>0,05$.

Adapun penelitian hipotesis $\mathrm{H}_{\mathrm{a}}$ dan $\mathrm{H}_{\mathrm{o}}$ sebagai berikut:

$\mathrm{H}_{\mathrm{o}} \quad$ : Tidak terdapat pengaruh media pembelajaran kartu kuartet terhadap prestasi belajar siswa kelas IV SDN 1 Linggawangi materi gaya.

$\mathrm{H}_{\mathrm{a}} \quad$ : Terdapat pengaruh media pembelajaran kartu kuartet terhadap prestasi belajar siswa kelas IV SDN 1 Linggawangi materi gaya.

Tabel 5. Hasil independent samples t-test

\begin{tabular}{|c|c|c|c|c|c|c|c|c|c|c|}
\hline & & \multicolumn{2}{|c|}{$\begin{array}{l}\text { Levene's } \\
\text { Test for } \\
\text { Equality of } \\
\text { Variances }\end{array}$} & \multicolumn{7}{|c|}{ t-test for Equality of Means } \\
\hline & & \multirow[b]{2}{*}{$\mathrm{F}$} & \multirow[b]{2}{*}{ Sig. } & \multirow[b]{2}{*}{$\mathrm{T}$} & \multirow[b]{2}{*}{ df } & \multirow[t]{2}{*}{$\begin{array}{l}\text { Sig. } \\
(2- \\
\text { tailed) }\end{array}$} & \multirow[t]{2}{*}{$\begin{array}{c}\text { Mean } \\
\text { Differenc } \\
e\end{array}$} & \multirow[t]{2}{*}{$\begin{array}{l}\text { Std. Error } \\
\text { Difference }\end{array}$} & \multicolumn{2}{|c|}{$\begin{array}{l}\text { 95\% Confidence } \\
\text { Interval of the } \\
\text { Difference }\end{array}$} \\
\hline & & & & & & & & & Lower & Upper \\
\hline Prestasi & $\begin{array}{l}\text { Equal } \\
\text { variances } \\
\text { assumed }\end{array}$ & .566 & .462 & 4.445 & 18 & .000 & 22.000 & 4.950 & 11.601 & 32.399 \\
\hline $\begin{array}{l}\text { Belajar } \\
\text { Siswa }\end{array}$ & $\begin{array}{l}\text { Equal } \\
\text { variances } \\
\text { not } \\
\text { assumed }\end{array}$ & & & 4.445 & 17.120 & .000 & 22.000 & 4.950 & 11.563 & 32.437 \\
\hline
\end{tabular}

Hasil dari uji t-test terhadap prestasi hasil belajar siswa pada tema 7 subtema 2 mata pelajaran IPA materi gaya, dapat dilihat bahwa nilai signifikansi sebesar $0,000<0,05$ maka $\mathrm{H}_{\mathrm{o}}$ ditolak dan $\mathrm{H}_{\mathrm{a}}$ diterima. Berdasarkan hasil uji hipotesisi diatas, maka penelitian ini terdapat pengaruh media pembelajaran kartu kuartet terhadap prestasi belajar siswa kelas IV SDN 1 Linggawangi pada mata pelajaran IPA materi gaya. Hasil belajar siswa sebelum diberikan perlakuan yaitu pretest pada materi 
Nisa Awaliyah, M. Fabmi Nugraha, Budi Hendrawan/Cendekiawan Vol 3 (No. 2) (2021)

gaya memiliki nilai rata-rata yang tidak jauh berbeda. Setelah proses pemberian perlakuan pada kelas eksperimen menggunakan media pembelajaran kartu kuartet sedangkan pada kelas kontrol menggunakan model pembelajaran konvensional.

\section{PEMBAHASAN}

Pada pagian pembahasan ini, penelitian dilakukan di SDN 1 Linggawangi Kecamatan Leuwisari Kabupaten Tasikmalaya. Penelitian ini telah dilakukan pada seluruh siswa kelas IV SDN 1 Linggawangi berjumlah 20 siswa, yang dibagi menjadi dua kelas diantaranya 10 siswa kelas eksperimen yang diberikan perlakuan dengan media pembelajaran kartu kuartet dan 10 siswa kelas kontrol diberikan perlakuan dengan menggunakan model pembelajaran konvensional dalam bentuk ceramah. Seperti yang disampaikan (Putri et al., 2019) bahwa sampel merupakan subjek yang digunakan dalam penelitian. Penelitian dilakukan untuk mengetahui pengaruh media pembelajaran kartu kuartet terhadap prestasi belajar siswa pada mata pelajaran IPA materi gaya pada siswa kelas IV, hal itu juga disinggung oleh (Sugiyono \& Maryani, 2008) bahwa untuk mengetahui suatu pengaruh dari penggunaan media kartu kuartet siswa harus menerapkan pembelajaran tersebut.

Tahap awal untuk mengumpulkan hasil penelitian menggunakan teknik pretest, hal ini dilakukan oleh seluruh siswa kelas IV dan hasil yang didapat dari pretest kelas kontrol memiliki nilai rata-rata 54,5 dan kelas eksperimen memiliki nilai rata-rata 60,0 sehingga nilai rata-rata kelas eksperimen dan kelas kontrol memiliki nilai rata-rata yang tidak jauh berbeda. Seperti yang disampaikan (Purwanti et al., 2019) bahwa nilai pretes dan nilai posttest merupakan dua nilai yang dibandingkan dan dapat menyimpulkan hasil penelitian.

Selanjutnya peneliti memberikan perlakuan kepada kelas eksperimen dengan perlakuan menggunakan media pembelajaran kartu kuartet sedangkan kelas kontrol diberi perlakuan dengan menggunakan model pembelajaran konensional. Perlakuan kelas eksperimen dilkukan untuk kelas yang menggunakan kartu kuartet atau media pembelajaran (Muyaroah \& Fajartia, 2017). Setelah selesai diberi perlakuan kedua kelas diberikan posttest untuk mengetahui hasil perlakuan yang telah diberikan dan nilai rata-rata kelas eksperimen yaitu 83,5 sedangkan kelas kontrol nilai rata-ratanya yaitu 61,5. Nilai rata-rata kelas ekperimen lebih tinggi dibandingkan dengan kelas kontrol sehingga jauh berbeda. Berdasarkan validitas menggunakan SPSS versi 20 dinyatakan semua valid dari seluruh soal yang berjumlah 20 soal.

Uji normalitas menggunakan uji Shapiro-Wilk dengan SPSS versi 20. Dengan ketentuan jika sig $<0.05$ maka data tidak berdistribusi normal dan jika nilai sig $>0.05$ maka data berdistribusi normal. Dengan hasil uji normalitas menggunakan uji Shapiro-Wilk dengan SPSS versi 20 maka akan lebih memudahkan dalam perhitungan dan lebih akurat (Setyaningsih, 2015).

Uji homogenitas untuk mengetahui kedua data tersebut bersifat homogen sama atau tidak (Fahmawati et al., 2017). Dalam penelitian ini uji homogenitas menggunakan rumus One Way Anova dengan perhitungan SPSS versi 20. Seperti yang disampaikan bahwa rumus One Way Anova lebih efektiv dengan aplikasi SPSS (Aini, 2018).

Berdasarkan hasil uji hipotesisi, maka penelitian ini terdapat pengaruh media pembelajaran kartu kuartet terhadap prestasi belajar siswa kelas IV SDN 1 Linggawangi pada mata pelajaran IPA materi gaya. Dengan adanya mata pelajaran IPA materi gaya sesuai dengan silabus dan buku ajar siswa (Katolik \& Thomas, 2021).

\section{SIMPULAN}

Pada siswa kelas eksperimen saat proses pembelajaran berlangsung siswa menjadi fokus dan antusias dalam mengikuti proses pembelajaran dan berpengaruh pada prestasi belajar siswa dengan hasil yang diperoleh dari nilai rata-rata posttest dengan adanya peningkatan lebih besar dari kelas kontrol yaitu 83,5 > 61,5. Berdasarkan hasil uji hipotesis menggunakan SPSS versi 20 diperoleh 
Nisa Awaliyah, M. Fahmi Nugraha, Budi Hendrawan/Cendekiawan Vol 3 (No. 2) (2021)

nilai sig $0,000<0,05$ maka $\mathrm{H}_{\mathrm{o}}$ ditolak dan $\mathrm{H}_{\mathrm{a}}$ diterima. Sehingga hasil penelitian ini adalah terdapat pengaruh media pembelajaran kartu kuartet terhadap prestasi belajar siswa kelas IV SDN 1 Linggawangi materi gaya.

\section{REFERENSI}

Arifin. 2011. Metode Penelitian Kualitatif, Kuantitatif, dan R \& D. Bandung: Alfabeta.

Andi Prastowo. 2014. Panduan Kreatif Membuat Bahan Ajar Inovatif. Yogyakarta: Diva Press.

Arsyad, Azhar. 2006. Media Pembelajaran. Jakarta: Rineka Cipta.

Fathurrahman, M dan Sulistyorini. 2012. Belajar Dan Pembelajaran Meningkatkan Mutu Pembelajaran Sesuai Standar Nasional. Yogyakarta: Teras.

Trianto. 2010. Mengembangkan Model Pembelajaran Tematik. Surabaya: Prestasi Pustaka.

Ai Parihah, M. Fahmi Nugraha, A. S. P. (2020). The Effect of the Chain Writing Method on the Writing Skills of Class V Elementary School Students. Cendekiawan, 2(2), 83-87. Cendekiawan.unmuhbabel.ac.id

Aini, F. N. (2018). Pengaruh Game Based Learning Terhadap Minat Dan Hasil Belajar Pada Mata Pelajaran Ekonomi Siswa Kelas Xi Ips. Jurnal Pendidikan Ekonomi (JUPE), 6(3), 249-255.

Akmal, S., \& Susanti, E. (2019). Analisis Dampak Penggunaan Reward Dalam Pembelajaran Pendidikan Agama Islam Di Sma Muhammadiyah Aceh Singkil. Jurnal Ilmiah DIDAKTIKA, 19(2), 159-177.

Depdiknas. 2003. Undang-Undang RI Nomor 20, Tahun 2003, tentang Sistem Pendidikan Nasional.

Fahmawati, F., Rusdi, R., \& Komala, R. (2017). Pengaruh Model Pembelajaran Survey, Question, Read, Recite, Review (SQ3R) dan Kemampuan Berpikir Kritis terhadap Hasil Belajar Peserta Didik SMA. Jurnal Pendidikan Biologi, 10(2), 55-62. https://jurnal.uns.ac.id/bioedukasi/article/view/17606

iwangsa, S. F. (2021). Pengembangan Media Kartu Kuartet Pada Pembelajaran Ips Sekolah Dasar the Development of Quartet Card Media in Learning Social Studies Elementary Schools. Pedagogi: Jurnal Penelitian Pendidikan, 8(1), 40-48. https://doi.org/10.25134/pedagogi.v8i1.3992

Istiningsih. (2017). Empowerment of Teachers in Implementing Thematic Learning Method. Empowerment of Teachers in Implementing Thematic Learning Method, 8(3), 64-70.

Jalil, M. (2016). Pengembangan Pembelajaran Model Discovery Learning Berbantuan Tips Powerpoint Interaktif Pada Materi Interaksi Makhluk Hidup Dengan Lingkungan. Refleksi Edukatika, 6(2), 130-137. https://doi.org/10.24176/re.v6i2.604

Karsono, Sujana, Y., Daryanto, J., \& Yustinus, N. (2014). Penggunaan Kartu Kuartet Untuk Meningkatkan Pemahaman Keberagaman Seni Tradisi Nusantara Pada Siswa Sekolah Dasar. Mimbar Sekolah Dasar, 1(April), 43-49.

Katolik, U., \& Thomas, S. (2021). Upaya Meningkatkan Hasil Belajar Siswa dengan Menggunakan Media Animasi pada Siswa Sekolah Dasar Linda Simanjuntak $1 \square$, Patri Janson Silaban 2 , Anton Sitepu 3. Jurnal Basicedu, 5(5), 3559-3565. 
Muyaroah, S., \& Fajartia, M. (2017). Pengembangan Media Pembelajaran Berbasis Android dengan menggunakan Aplikasi Adobe Flash CS 6 pada Mata Pelajaran Biologi. Innovative Journal of Curriculum and Educational Technology, 6(2), 22-26. https://doi.org/10.15294/ijcet.v6i2.19336

Purwanti, D., . G., \& Musadad, A. A. (2019). The Effect of Local-Based 2013 Curriculum Implementation on Students' Environmental Awareness. International Journal of Educational Research Review, 4(1), 65-75. https://doi.org/10.24331/ijere.486241

Putri, I. S., Solih, S., \& Handoyo, A. W. (2019). The Effectiveness of Cooperative Game Techniques to Improve Social Skills of State Elementary School Students 2 Curugbarang Pandeglang. Cendekiawan, 1(2), 51-60. https://doi.org/10.35438/cendekiawan.v1i2.168

Reni, Permana, R., \& Nugraha, M. F. (2020). Pengaruh model pembelajaran savi dan tingkat kepercayaan diri terhadap prestasi belajar siswa. Cendekiawan, 2(2), 88-94. https://doi.org/https://doi.org/10.35438/cendekiawan.v2i2.186

Rozalia, Ferdiana, M. 2017. Hubungan Intensitas Pemanfaatan gadget dengan prestasi belajar siswa kelas V Sekolah Dasar. Jurnal Pendidikan dan Pengembangan SD, Vol. 5 No. 2, 722-731.

Sugiyono. 2016. Metode Penelitian Pendidikan (Pendekatan Kuantitatif, Kualitatif, dan R\&D). Bandung: Alfabeta.

Sukmadinata, Nana Syaodih. 2016. Metode Penelitian Pendidikan. Bandung: PT Remaja Rosdakarya.

Suryabrata, Sumadi, 2011. Psikologi Pendidikan, Jakarta: PT. Raja Grafindo Persada.

Sari, I. P., Sari, S. A., \& Rahmayani, R. F. I. (2017). Pengembangan Media Kartu Kuartet Pada Materi Asam Basa Untuk Meningkatkan Motivasi Dan Aktivitas Belajar Siswa Kelas Vii Di Smp Negeri 6 Banda Aceh Abstrak Pendahuluan Metode Penelitian. Jurnal Ilmiah Mabasiswa Pendidikan Kimia, 2(1), 1-10.

Sasmita, S. (2017). Penggunaan Media Permainan Kartu Kwartet Pintar Sejarah (Kkps) Dalam Upaya Peningkatan Aktivitas Dan Hasil Belajar Pada Siswa Kelas X Ipa 7 Sma Negeri 1 Surakarta Semester Gasal Tahun Pelajaran 2017/2018. Jurnal Artefak, 4(2), 119. https://doi.org/10.25157/ja.v4i2.905

Setyaningsih, E. (2015). Efektivitas Pelaksanaan Praktikum Anatomi Hewan Pendidikan Biologi FKIP UMS Tahun 2011/2012 dan 2012/2013 Ditinjau dari Nilai Akhir Praktikum. Jurnal Bioedukatika, 3(2), 21. https://doi.org/10.26555/bioedukatika.v3i2.4150

Sugiyono, \& Maryani, Y. (2008). Kamus Besar Bahasa Indonesia.

Trisnawati, D. (2013). Implementasi Pembelajaran Berbasis Budaya pada Kelas IV di SD Negeri Godean 2 Sleman Yogyakarta. In Journal of Chemical Information and Modeling (Vol. 53, Issue 9). 